\title{
Fertiliser value of human manure from pilot urine-diversion toilets
}

\author{
PNS Mnkeni* and LM Austin ${ }^{2}$ \\ ${ }^{1}$ Department of Agronomy, Faculty of Science and Agriculture, University of Fort Hare, Private Bag X1314 Alice, 5700, South Africa \\ ${ }^{2}$ CSIR Built Environment Unit, PO Box 395, Pretoria 0001, South Africa
}

\begin{abstract}
Ecological sanitation is a system that, unlike the traditional waterborne sewerage and pit toilet systems, regards human excreta as a resource to be recycled rather than as a waste. There is, however, little or no information on the fertiliser value of human excreta in South Africa. This study, therefore, evaluated the effectiveness of human manure as a source of nutrients using cabbage as a test crop at Ntselamanzi location, Alice, South Africa as part of a project intended to generate knowledge and good practice in ecological sanitation. Treatments were arranged in a randomised complete block design with 4 replications and consisted of a control, $100 \mathrm{~kg} \mathrm{~N} \cdot \mathrm{ha}^{-1}$ as goat manure, and 4 non-zero rates of human manure and NPK fertiliser applied to supply the equivalent of 50,100, 200, and $400 \mathrm{~kg} \mathrm{~N} \cdot \mathrm{ha}^{-1}$.

Human manure resulted in higher cabbage yields than goat manure but was out-yielded by inorganic fertiliser. The greater effectiveness of human manure when compared with goat manure was attributed to the fact that it was a better source of $\mathrm{K}$ and $\mathrm{P}$ for plants as it maintained higher levels of these nutrients in soil than goat manure. For greater agronomic effectiveness, the human manure should be co-applied with some inorganic $\mathrm{N}$ fertiliser as it proved to be a poor source of nitrogen. The human manure increased soil $\mathrm{pH}$ and therefore has potential for improving crop growth in acidic soils through its liming effects as well. The dry human manure was evaluated as comparable to Type B sludge in South Africa with respect to microbial content and could therefore be used to fertilise some crops/plants provided stipulated restrictions to minimise human exposure are adhered to.
\end{abstract}

Keywords: ecological sanitation, urine-diversion toilets, human manure, Type B sludge, goat manure, cabbage, recycling nutrients, South Africa

\section{Introduction}

Most rural and peri-urban households in South Africa are not yet connected to a sanitation system for proper management of their wastes. According to Austin and Ducker (2002) both financial and water resources are also scarce in some of these areas making a water-carrier sewage system inappropriate because it requires lots of water and is costly to install. Most of these areas are also faced with a worsening problem of soil fertility decline and low yields caused by soil fertility depletion resulting from exhaustive cropping and insufficient return of nutrients to the land (Laker, 1976; Mandiringana et al., 2005). An ideal sanitation system for these areas is one that would:

- Not require expensive reticulation systems

- Conserve water

- Allow the safe recovery and recycling of nutrients from human excreta for soil fertility improvement.

\footnotetext{
* To whom all correspondence should be addressed.

푤 +27406022139; fax: +27866262923 ; e-mail:pmnkeni@ufh.ac.za
}

Received 30 May 2008; accepted in revised form 8 December 2008.

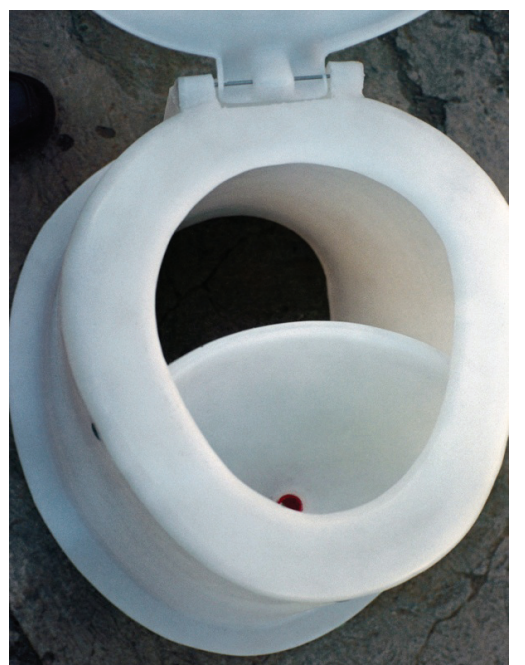

(a)

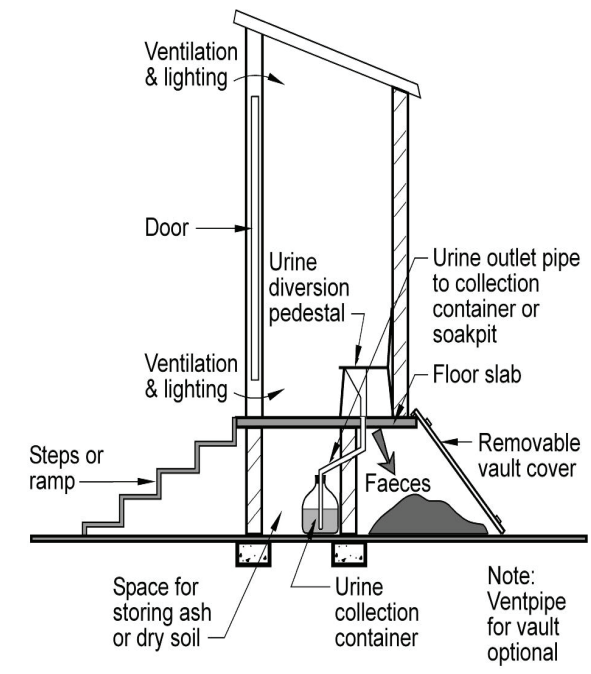

(b)
Figure 1

Urine diversion pedestal (a) and schematic representation of a urine-diversion ('dry box') toilet (b)

Ecological sanitation (ECOSAN) toilets have been designed to meet these goals (Simpson-Herbert, 1997). The most common ECOSAN toilet is the urine-diverting type in which the urine is diverted away from faeces via a specially designed pedestal (Fig. 1). These toilets use little or no water and the excreta is not discharged or buried in deep pits. This system is thus better than the conventional latrine-based systems common in many rural 
areas in Africa, as it enables the hygienic recovery of faeces and urine for possible use as soil amendments.

Urine contains few pathogenic micro-organisms but may contain Ascaris ova and Schistosoma eggs (Drangert, 1998). However, human faeces always contain high amounts of enteric micro-organisms including many pathogens and opportunistic pathogens, even when the affected person does not experience any symptoms (Heinonen-Tanski and van Wijk-Sijbesma, 2005). The faeces from ECOSAN toilets are sanitised to some extent in the collection chamber of the toilet through drying and the addition of lime or wood ash. The lime or wood ash raises the $\mathrm{pH}$ and accelerates pathogen destruction. On average a person produces between 30 and $110 \mathrm{~kg}$, wet weight, of faeces per year corresponding to 10 to $15 \mathrm{~kg}$ of dry matter (Lentner et al., 1981; Vinneras, 2002).

The amounts of nutrients found in urine and faeces vary from person to person and from region to region depending on the nutrient content of the food consumed (Vinnerås and Jönsson, 2002). Urine has a high content of readily available nitrogen, phosphorus and potassium and its fertilising effect is reported to be similar to that of nitrogen-rich chemical fertiliser (Kirchman and Petterson, 1995). Faeces on the other hand have high contents of phosphorus and potassium in ionic form but the nitrogen is only slowly released as it is organically bound in undigested food remains (Kirchman and Petterson, 1995). Both waste materials, however, have great potential for improving the fertility of impoverished soils.

The technology of ecological sanitation or 'dry box toilets' has been used successfully for many years in a number of countries, e.g. Vietnam, China, Mexico, El Salvador, Guatamala, Ethiopia, Zimbabwe and Sweden (Esrey et al., 1998; Wolgast, 1993; and Esrey and Andersson, 2001). Ecological sanitation is, however, not yet widely used in South Africa despite the obvious benefits of the approach. To address this shortcoming a project was undertaken to develop good practices for ecological sanitation in South Africa in terms of toilet design and agronomic uses of products of ECOSAN toilets.

South African studies on the fertiliser value of human urine were reported previously (Mnkeni et al., 2005; 2008) but only preliminary local results have so far been reported on the agronomic effectiveness of human manure (Mnkeni et al., 2006; Mnkeni and Austin, 2008). This paper reports results of a study that evaluated the fertiliser value of dry faeces from pilot urinediversion (UD) toilets.

\section{Materials and methods}

The trial site was the KwaSomgxada Community Garden at Ntselamanzi location, located between latitudes $32^{\circ} 46^{\prime} 52^{\prime \prime}$ and $32^{\circ} 46^{\prime} 46^{\prime \prime} \mathrm{S}$ and longitudes 26 $50^{\prime} 26^{\prime \prime}$ and $26^{\circ} 50^{\prime} 46^{\prime \prime} \mathrm{E}$ in Alice, Eastern Cape Province, South Africa. The soil was classified as the Ritchie family of the Oakleaf form in the South African soil classification system (Soil Classification Working Group, 1991), and as a Eutric Cambisol in the World Reference Base for Soil Resources (WRB) system (IUSS Working Group WRB, 2006). A participatory field trial to determine the fertiliser value of human manure using cabbage (Brassica oleracea) as a test crop was established in collaboration with members of the KwaSomgxada Community Garden Project at Ntselamanzi location in Alice. Cabbage seedlings were transplanted on 18 June 2003 on pre-irrigated plots measuring $3 \mathrm{~m} \mathrm{x} 3 \mathrm{~m}$ at a spacing of $50 \mathrm{~cm} \times$ $50 \mathrm{~cm}$, resulting in a plant population of 36 plants per plot. The experimental design was a randomised complete block design with 11 treatments (Table 1) and 4 replications.

The human manure was obtained from UD toilets in Mthatha, Eastern Cape Province, South Africa while goat manure was obtained from the University of Fort Hare Honeydale Livestock Research Farm. Ground dry manure samples sieved to pass through a $2 \mathrm{~mm}$ sieve were analysed for selected properties following procedures described for soil samples below. The dry human manure and goat manure had total $\mathrm{N}$ contents of 18 and $26 \mathrm{~g} \cdot \mathrm{kg}^{-1}$, respectively (Table 2 ). The rates of application were based on nitrogen since this is often the most growth-limiting nutrient. Only one rate of goat manure was included for comparative purposes.

The dry goat and human manure samples were sieved through an $8 \mathrm{~mm}$ sieve prior to application. All manure treatments were broadcast and manually incorporated in the top 200 $\mathrm{mm}$ of soil using hoes, followed by irrigation, one week before cabbage seedlings were transplanted. Basal applications of $\mathrm{P}$ and $\mathrm{K}$ applied in combination with the inorganic fertiliser treatments were at recommended rates for cabbage based on soil tests done by the Fertiliser Advisory Service of the Döhne Agricultural Development Institute, Stutterheim, South Africa. The

\begin{tabular}{|c|c|c|c|c|}
\hline \multicolumn{5}{|c|}{$\begin{array}{l}\text { TABLE } 1 \\
\text { Experimental treatments and their } \mathrm{N}, \mathrm{P} \text {, and } \mathrm{K} \text { inputs }\end{array}$} \\
\hline \multirow[t]{2}{*}{$\begin{array}{l}\text { Treatment } \\
\text { No. }\end{array}$} & \multirow[t]{2}{*}{ Treatment details } & \multicolumn{3}{|c|}{$\begin{array}{l}\text { Amount of primary fertiliser } \\
\text { nutrients supplied }\left(\mathrm{kg} \cdot \mathrm{ha}^{-1}\right)\end{array}$} \\
\hline & & $\mathbf{N}$ & $\mathbf{P}$ & $\mathrm{K}$ \\
\hline 1 & Control A - No fertiliser or manure & 0 & 0 & 0 \\
\hline 2 & $\begin{array}{l}\text { Control B - Basal dressing equivalent to } 95 \mathrm{~kg} \mathrm{P}^{\mathrm{h}} \mathrm{ha}^{-1} \text { (as TSP) }+90 \mathrm{~kg} \\
\mathrm{~K}^{-1} \mathrm{a}^{-1} \text { (as muriate of potash). No N application }\end{array}$ & 0 & 95 & 90 \\
\hline 3 & $50 \mathrm{~kg} \mathrm{~N} \cdot \mathrm{ha}^{-1}$ as LAN + Basal P and $\mathrm{K}$ dressing & 50 & 95 & 90 \\
\hline 4 & $100 \mathrm{~kg} \mathrm{~N} \cdot \mathrm{ha}^{-1}$ as LAN + Basal P and $\mathrm{K}$ dressing & 100 & 95 & 90 \\
\hline 5 & $200 \mathrm{~kg} \mathrm{~N} \cdot \mathrm{ha}^{-1}$ as LAN + Basal P and $\mathrm{K}$ dressing & 200 & 95 & 90 \\
\hline 6 & $400 \mathrm{~kg} \mathrm{~N} \cdot \mathrm{ha}^{-1}$ as LAN + Basal P and K dressing & 400 & 95 & 90 \\
\hline 7 & $50 \mathrm{~kg} \mathrm{~N} \cdot \mathrm{ha}^{-1}$ as HM $\left(18 \mathrm{~g} \mathrm{~N} \cdot \mathrm{kg}^{-1}\right)$. No basal $\mathrm{P}$ and $\mathrm{K}$ dressing & 50 & 8.4 & 123 \\
\hline 8 & $100 \mathrm{~kg} \mathrm{~N} \cdot \mathrm{ha}^{-1}$ as HM $\left(18 \mathrm{~g} \mathrm{~N} \cdot \mathrm{kg}^{-1}\right)$. No basal $\mathrm{P}$ and $\mathrm{K}$ dressing & 100 & 16.8 & 246 \\
\hline 9 & $200 \mathrm{~kg} \mathrm{~N} \cdot \mathrm{ha}^{-1}$ as HM $\left(18 \mathrm{~g} \mathrm{~N} \cdot \mathrm{kg}^{-1}\right)$. No basal $\mathrm{P}$ and $\mathrm{K}$ dressing & 200 & 33.6 & 493 \\
\hline 10 & $200 \mathrm{~kg} \mathrm{~N} \cdot \mathrm{ha}^{-1}$ as HM $\left(18 \mathrm{~g} \mathrm{~N} \cdot \mathrm{kg}^{-1}\right)$. No basal P and $\mathrm{K}$ dressing & 400 & 67.2 & 986 \\
\hline 11 & $100 \mathrm{~kg} \mathrm{~N} \cdot \mathrm{ha}^{-1}$ as GM $\left(26 \mathrm{~g} \mathrm{~N} \cdot \mathrm{kg}^{-1}\right)$. No basal $\mathrm{P}$ and $\mathrm{K}$ dressing & 100 & 15.2 & 174 \\
\hline
\end{tabular}

$L A N=$ limestone ammonium nitrate $(28 \% \mathrm{~N}), H M=$ human manure (dry faeces), GM = goat manure 
TABLE 2

Chemical composition of the human manure and goat manure used in the study

\begin{tabular}{|c|c|c|c|c|c|c|c|c|c|c|c|c|c|c|}
\hline \multirow{3}{*}{$\begin{array}{l}\text { Manure } \\
\text { type }\end{array}$} & $\mathrm{pH}$ & EC & \multirow[t]{3}{*}{ C: $N$} & \multirow[t]{3}{*}{ C: P } & \multicolumn{10}{|c|}{ Total elemental composition } \\
\hline & \multirow{2}{*}{\multicolumn{2}{|c|}{$\begin{array}{c}\text { (1.2.5 manure: } \\
\text { water) }\end{array}$}} & & & C & $\mathbf{N}$ & $\mathbf{P}$ & $\mathrm{K}$ & $\mathrm{Ca}$ & Mg & Mn & $\mathrm{Fe}$ & $\mathrm{Cu}$ & $\mathrm{Zn}$ \\
\hline & & & & & \multicolumn{6}{|c|}{$\mathbf{g} \cdot \mathbf{k g}^{-1}$} & \multicolumn{4}{|c|}{$\mathbf{m g} \cdot \mathbf{k g}^{-1}$} \\
\hline $\begin{array}{l}\text { Human } \\
\text { manure }\end{array}$ & 7.5 & 3.3 & 13 & 80 & 240 & 18 & 3 & 44 & 4 & 7.9 & 35 & 52 & 6.3 & 33 \\
\hline $\begin{array}{l}\text { Goat } \\
\text { manure }\end{array}$ & 7.5 & 3.1 & 10 & 63 & 250 & 26 & 4 & 46 & 7 & 12.1 & 48 & 73 & 7.6 & 37 \\
\hline
\end{tabular}

$\mathrm{P}$ and $\mathrm{K}$ treatment (Control $\mathrm{B}$ ) was included to determine crop performance in the absence of nitrogen, but with adequate $\mathrm{P}$ and $\mathrm{K}$. The $\mathrm{P}$ and $\mathrm{K}$ were broadcast just before transplanting, while $\mathrm{N}$ treatments as LAN were top-dressed 4 weeks after transplanting.

Members of the KwaSomgxada Community Garden Project were responsible for day-to-day maintenance of the plots with oversight from the researchers. The crop was grown under irrigation using a dragline sprinkler irrigation system with water pumped from the nearby Tyume River. Irrigation was managed by the host farmer, and generally consisted of two irrigation cycles of $3 \mathrm{~h}$ each per week. Harvesting was done on 19 November 2003 from a net plot area of $4 \mathrm{~m}^{2}$ achieved by disregarding the outer (guard) rows in each plot. The harvested cabbage heads were weighed on site but were later transported to the laboratory where sub-samples were taken for dry matter determination and nutrient $(\mathrm{N}, \mathrm{P}$ and $\mathrm{K}$ ) analysis. Total $\mathrm{N}$ was determined by dry combustion using a LECO TRUSPEC $\mathrm{C}$ and $\mathrm{N}$ auto-analyser (LECO Corporation, 2003) while total $\mathrm{P}$ and $\mathrm{K}$ were determined following wet digestion with $\mathrm{H}_{2} \mathrm{O}_{2} / \mathrm{H}_{2} \mathrm{SO}_{4}$ as described by Okalebo et al., (2002). Total $\mathrm{K}$ in digested samples was determined by AAS while total $\mathrm{P}$ was determined by the molybdenum-blue method (Olsen and Sommers, 1982).

Soil samples were taken after harvest from the top $15 \mathrm{~cm}$ soil of each plot, air dried, and ground to pass through a $2 \mathrm{~mm}$ sieve; and analysed for total carbon, soil $\mathrm{pH}$, electrical conductivity (EC), and selected macro- and micronutrients. Total $\mathrm{C}$ was determined by dry combustion using a LECO TRUSPEC $\mathrm{C}$ and $\mathrm{N}$ auto-analyser. Soil $\mathrm{pH}$ was measured in water at a soil: water ratio of 1:2.5 using a $\mathrm{pH}$ meter with a glass and reference calomel electrode (Model pH 330 SET-1, 82362, Weilheim, Germany) after the soil suspensions were shaken for 30 minutes and equilibrated for $1 \mathrm{~h}$. Electrical conductivity was measured in water at a 1: 2.5 soil: water ratio using a conductivity meter (Model Cond.330i/SET 82362, Weilheim, Germany). The extractable cations $\mathrm{Ca}^{2+}, \mathrm{Mg}^{2+}, \mathrm{K}^{+}, \mathrm{Na}^{+}, \mathrm{Cu}^{2+}$ and $\mathrm{Zn}^{2+}$ were extracted using the Ambic 1 procedure (Van der Merwe et al., 1984) and analysed by AAS. Soil-extractable P was also extracted using the Ambic-1 procedure and the $\mathrm{P}$ concentration in the extract determined by the molybdenum-blue method (Olsen and Sommers, 1982).

\section{Data analysis}

Some seedlings failed to establish on some plots so covariance analysis was conducted on the cabbage yield data with plant population as the covariate in order to eliminate the effects of uneven plant stand. The rest of the data was subjected to analysis of variance (ANOVA) using the MSTATC statistical package. Means separation was done using Duncan's Multiple Range Test (DMRT) at the 0.05 level of significance.

\section{Results and discussion}

Goat and human manure had comparable $\mathrm{pH}$ and $\mathrm{EC}$ values (Table 2). The EC values were very low, suggesting that soil application of both amendments should not cause salinity problems. The $\mathrm{pH}$ of the manures was slightly alkaline, indicating that their application to acidic soils would have a liming effect. Human manure had lower concentrations of all macro and micro nutrients determined than goat manure (Table 2), suggesting that human manure would be a poorer source of nutrients. The $\mathrm{C}: \mathrm{N}$ and $\mathrm{C}$ : $\mathrm{P}$ ratios of the two manures were well below the cutoff ranges for decomposition of organic materials and release of $\mathrm{N}$ and P. However, the C: $\mathrm{N}$ and $\mathrm{C}$ : $\mathrm{P}$ ratios of goat manure were lower than those of human manure, suggesting that the goat manure could decompose and release its $\mathrm{N}$ and $\mathrm{P}$ more readily.

Inorganic $\mathrm{N}$ fertiliser substantially increased cabbage yields above both control treatments (Controls A and B), as well as the goat manure treatment (Table 3, next page). The highest yield was obtained with the LAN application of $100 \mathrm{~kg} \mathrm{~N} \cdot \mathrm{ha}^{-1}$ inorganic $\mathrm{N}$ and not the recommended rate of $200 \mathrm{~kg} \mathrm{~N} \cdot \mathrm{ha}^{-1}$. The $100 \mathrm{~kg} \mathrm{~N} \cdot \mathrm{ha}^{-1}$ treatment was the only one that gave a statistically significantly higher yield than both controls, as well as being the only one to give a significantly higher yield than the lowest inorganic $\mathrm{N}$ treatment, the human manure and goat manure treatments.

Observations during the growing season showed that inorganic N application rates above $100 \mathrm{~kg} \mathrm{~N} \cdot \mathrm{ha}^{-1}$ supported bigger plants but these failed to head properly as a result of the lush growth. In contrast to inorganic fertiliser, rates of human manure application equivalent to $50-200 \mathrm{~kg} \mathrm{~N} \cdot \mathrm{ha}^{-1}$ increased yield only slightly and more or less to the same extent (Table 3 ). Only the highest rate of human manure application $\left(400 \mathrm{~kg} \mathrm{~N} \cdot \mathrm{ha}^{-1} \equiv 21.6\right.$ tha ${ }^{-1}$ of human manure) caused a substantial increase in yield. This could be explained by the fact that nutrients in inorganic fertiliser are immediately available to growing plants, whereas a large proportion of nutrients in both human and goat manures are organically bound in undigested food/feed remains and become only slowly available through mineralisation (Kirchman and Petterson, 1995). The results suggest that for human manure to have an effect on cabbage under our experimental conditions, at least $20 \mathrm{t} \cdot \mathrm{ha}^{-1}$ has to be applied.

Human manure at a rate $100 \mathrm{~kg} \mathrm{~N} \cdot \mathrm{ha}^{-1}$ resulted in slightly, but not statistically significantly, better yield than goat manure at the same rate (Table 3 ). This yield difference was not related to tissue $\mathrm{N}$ as human manure and goat manure at this rate, produced similar levels of $\mathrm{N}$ in the plants (Table 3 ). This was contrary to expectations that goat manure would have resulted in higher tissue $\mathrm{N}$ levels in plants as a result of its higher $\mathrm{N}$ content and narrower C: $\mathrm{N}$ ratio (Table 2). Human manure at $400 \mathrm{~kg} \mathrm{~N} \cdot \mathrm{ha}^{-1}$ gave a substantial, but not statistically significantly higher, yield than goat manure at $100 \mathrm{~kg} \mathrm{~N} \cdot \mathrm{ha}^{-1}$. This was associated with a statisti- 


\begin{tabular}{|c|c|c|c|c|}
\hline \multicolumn{5}{|c|}{$\begin{array}{l}\text { TABLE } 3 \\
\text { Mean fresh yield and } \mathrm{N}, \mathrm{P} \text { and } \mathrm{K} \text { concentration of cabbage at harvest time }\end{array}$} \\
\hline \multirow[t]{2}{*}{ Treatment } & \multirow{2}{*}{$\begin{array}{c}\text { Fresh yield } \\
t^{t} \cdot \text { ha }^{-1}\end{array}$} & $\mathbf{N}$ & $\mathbf{P}$ & $\mathrm{K}$ \\
\hline & & \multicolumn{3}{|c|}{$\mathbf{g} \cdot \mathbf{k g}^{-1}$} \\
\hline Control A & $45 \mathrm{bcd}$ & $20 \mathrm{~d}$ & $1.3 \mathrm{e}$ & 19.5 \\
\hline Control B (basal P \& K) & $38 \mathrm{~d}$ & $22 \mathrm{~cd}$ & $1.5 \mathrm{cde}$ & 20.4 \\
\hline \multicolumn{5}{|l|}{ LAN + basal P\&K } \\
\hline $50 \mathrm{~kg} \mathrm{~N} \cdot \mathrm{ha}^{-1}$ & $56 \mathrm{bcd}$ & $27 \mathrm{~b}$ & $1.9 \mathrm{ab}$ & 24.2 \\
\hline $100 \mathrm{~kg} \mathrm{~N} \cdot \mathrm{ha}^{-1}$ & $77 \mathrm{a}$ & $29 \mathrm{~b}$ & $1.7 \mathrm{bcd}$ & 23.7 \\
\hline $200 \mathrm{~kg} \mathrm{~N} \cdot \mathrm{ha}^{-1}$ & $63 \mathrm{ab}$ & $35 \mathrm{a}$ & $2.1 \mathrm{a}$ & 24.6 \\
\hline $400 \mathrm{~kg} \mathrm{~N} \cdot \mathrm{ha}^{-1}$ & 56 bcd & $35 \mathrm{a}$ & $2.0 \mathrm{a}$ & 26.4 \\
\hline \multicolumn{5}{|l|}{ Human manure } \\
\hline $50 \mathrm{~kg} \mathrm{~N} \cdot \mathrm{ha}^{-1}$ & $49 \mathrm{bcd}$ & $21 \mathrm{~d}$ & $1.4 \mathrm{de}$ & 21.2 \\
\hline $100 \mathrm{~kg} \mathrm{~N} \cdot \mathrm{ha}^{-1}$ & 48 bcd & $20 \mathrm{~d}$ & $1.8 \mathrm{abc}$ & 23.3 \\
\hline $200 \mathrm{~kg} \mathrm{~N} \cdot \mathrm{ha}^{-1}$ & $49 \mathrm{bcd}$ & $22 \mathrm{~cd}$ & $1.6 \mathrm{bcd}$ & 25.0 \\
\hline $400 \mathrm{~kg} \mathrm{~N} \cdot \mathrm{ha}^{-1}$ & $58 \mathrm{bc}$ & $26 \mathrm{bc}$ & $1.8 \mathrm{abc}$ & 26.2 \\
\hline \multicolumn{5}{|l|}{ Goat manure } \\
\hline $100 \mathrm{~kg} \mathrm{~N} \cdot \mathrm{ha}^{-1}$ & $42 \mathrm{~cd}$ & $20 \mathrm{~d}$ & $1.5 \mathrm{cde}$ & 20.8 \\
\hline
\end{tabular}

Figures in a column followed by the same letter or none at all are not significantly different at $p<0.05$ according to Duncan's Multiple Range Test.

\begin{tabular}{|l}
\multicolumn{8}{|c|}{$\begin{array}{l}\text { TABLE 4 } \\
\text { Efects of human manure, goat manure and inorganic fertiliser on soil organic carbon, } \\
\text { electrical conductivity, pH and Ambic 1 extractable macro- and micronutrients }\end{array}$} \\
\hline \\
\hline
\end{tabular}

Figures in a column followed by the same letter or none at all are not significantly different at $p<0.05$ according to Duncan's Multiple Range Test.

cally significantly higher tissue $\mathrm{N}$ level in the plants fertilised at this human manure level than with the goat manure treatment, as well as in plants grown at the lowest two human manure treatments.

Human manure increased tissue $\mathrm{P}$ concentration relative to the absolute control but the increases were only statistically significant at rates of human manure application supplying 100 or more $\mathrm{kg} \mathrm{N} \cdot \mathrm{ha}^{-1}$ (Table 3). Human manure at all levels resulted in higher $\mathrm{K}$ concentrations in plants than goat manure, though the increases were not statistically significant (Table 3). Each increment in human manure application was accompanied by a corresponding increase in cabbage tissue $\mathrm{K}$ concentration. These results suggested that observed slight differences in yield could have been, at least partially, influenced by differences in the release patterns and availability of $\mathrm{P}$ and $\mathrm{K}$ from the goat and human manures.

Soil analysis after harvest showed that all the fertiliser and manure treatments maintained higher, but non-significant, levels of extractable P relative to control A (Table 4). However, soil P levels in all treatments, including the unfertilised control, were more than adequate for optimum crop production (FSSA, 2007). Therefore it is not surprising that yields were not significantly related to plant tissue P levels. Levels of extractable P in the inorganic fertiliser treatments were, as expected, more or less the same since they received a uniform rate of $\mathrm{P}$ application.

Comparison of treatments applied at the same rate of nitrogen $\left(100 \mathrm{~kg} \mathrm{~N} \cdot \mathrm{ha}^{-1}\right)$ showed that human manure resulted in higher levels of extractable $\mathrm{P}$ and $\mathrm{K}$ in the soil compared to goat manure (Table 4) even though the potential total $\mathrm{P}$ and $\mathrm{K}$ contribution of human manure was lower than that of goat manure (Table 2). Therefore, the higher tissue $P$ and $K$ concentration associated with human manure when contrasted with goat manure (Table 3) could be due to the greater ability of human manure to release and maintain higher levels of available $\mathrm{P}$ and $\mathrm{K}$ in the soil. These results are in agreement with those of Kirchman and Petterson, (1995) who also reported high levels of P and K in 
human faeces. It is possible that the human manure decomposed and released available $\mathrm{P}$ and $\mathrm{K}$ in soil more readily than goat manure because it contains fewer lignaceous materials than goat manure. However, it is also possible that the higher available $\mathrm{P}$ and $\mathrm{K}$ status of the human manure could have been, at least partially, contributed by the ash often used as a dehydrating/sanitising agent in ECOSAN toilets from which the human manure was collected. These findings suggest that the $\mathrm{P}$ and $\mathrm{K}$ in human manure is readily released and can have a positive effect on crop growth in $\mathrm{P}$ and $\mathrm{K}$ deficient soils. While the experimental soil had adequate levels of P (Table 4), there are many P-deficient soils in South Africa (Mandiringana et al., 2005; Henry and Smith, 2006) that could benefit from this amendment.

Inorganic fertiliser consistently decreased $\mathrm{pH}$ relative to the control (Table 4) even though the $\mathrm{N}$ source used was limestone ammonium nitrate (LAN), which contains some lime. Its continued use could in the long term lead to acidity problems at this site. By contrast, human manure had no effect on $\mathrm{pH}$ at low rates of application but increased it at the highest rate of application suggesting that its regular use could have a liming effect in acidic soils. This effect was consistent with the observed slightly alkaline $\mathrm{pH}$ of human manure (Table 2). These results suggest that applications of human (and goat) manure may in the long term raise soil $\mathrm{pH}$ to levels where it can induce trace element (notably Zn) deficiencies in crops. Fertiliser and manure treatments had no consistent effect on total $\mathrm{C}, \mathrm{EC}, \mathrm{Ca}, \mathrm{Mg}$, or $\mathrm{Cu}$ (Table 4). However, $\mathrm{Zn}$ levels in soil tended to decrease with increasing levels human manure application.

Generally, the results indicated that human manure has good fertiliser value especially with respect to $\mathrm{P}$ and $\mathrm{K}$. But evidently it is not a good source of $\mathrm{N}$, and therefore where used it should be applied with some inorganic $\mathrm{N}$ for greater effectiveness. The rate of human manure application should be based on the crop's $P$ requirements while inorganic $\mathrm{N}$ and $\mathrm{K}$ could be applied at rates calculated to supplement the amounts of these nutrients supplied by the human manure.

While the recycling of human manure through use as a soil amendment may reduce the need for chemical fertilisers in some soils, it also has the inherent risk of recycling pathogens found in human excreta if appropriate precautions are not taken (Höglund, 2001). This concern is even greater in developing countries where faecal material has high pathogen contents (Jiménez et al., 2002; 2004). Cisneros et al., (2006) showed that dry faecal material extracted from UD toilets in the eThekwini region of South Africa had a microbial content comparable to sludge classified as Type B in current South African regulations (WRC, 1997). In terms of these regulations, Type B sludge may not be used for:

- Household vegetables consumed raw or cooked or for tobacco production

- Private gardens (lawns, shrubs and vegetables).

It may, however, be used for other types of crops with some restrictions to minimise human exposure. These other crop types include vineyards and fruit trees (excluding private gardens), cereals and sugar cane, public gardens and traffic islands, public gardens and recreational areas, nurseries, crops for grazing and dry fodder production, grass or other crops for stabilising mine dumps, as well as natural veld and tree plantations (WRC, 1997). The human manure used in this study which was obtained from UD toilets in Mthatha could be considered similar to the one from eThekwini Municipality used by Cisneros et al., (2006). Therefore, although human manure was found to improve cabbage yields to some extent; it cannot be recom- mended for fertilising this and other household vegetable crops but can be considered as a soil amendment for the other crop types listed above.

\section{Conclusions}

Dry human manure resulted in higher cabbage yields than those yields achieved using goat manure but was inferior to inorganic fertiliser. The better agronomic effectiveness of human manure when compared to goat manure was attributed to its higher potassium and phosphate fertiliser value as it released and maintained higher levels of extractable $\mathrm{K}$ and $\mathrm{P}$ in soil. Human manure was however, a poor source of $\mathrm{N}$ so for greater agronomic effectiveness it should be co-applied with some inorganic fertiliser $\mathrm{N}$. Human manure increased soil $\mathrm{pH}$ and thus has the potential of improving crop growth in acidic soils through its liming effect as well. Based on these findings human manure from urinediversion toilet systems in South Africa has good potential for use in soil productivity improvement in certain sectors of South African agriculture where regulations allow the use of Type B sludges.

\section{Acknowledgements}

Financial support for this study was provided by the Water Research Commission (WRC) of South Africa. The authors are grateful to Mr Welcome Seti for help with the field trial and Mrs Siyasanga Mdana for laboratory analysis of the soil, manure and plant samples. Constructive comments by the anonymous reviewers are gratefully acknowledged. The views expressed in this paper are those of the authors and do not in any way reflect the views of the WRC, the CSIR or the University of Fort Hare.

\section{References}

AUSTIN A and DUCKER L (2002) Urine-Diversion Ecological Sanitation Systems in South Africa. CSIR Building and Construction Technology, Pretoria, South Africa.

CISNEROS BJ, PASHA MC and AUSTIN LM (2006) Microbiological effects on food crops fertilised with faecal material from urinediversion toilets. In: Mnkeni PNS, Cisneros, BJ, Pasha MC and Austin LM (2006) Use of Human Excreta from Urine-Diversion Toilets in Food Gardens: Agronomic and Health Aspects. WRC Report No. 1439/3/06. Water Research Commission, Pretoria, South Africa.

DRANGERT JO (1998) Fighting the urine blindness to provide more sanitation options. Water SA 24 157-164. http://www.wrc.org.za/ archives/watersa\%20archive/1998/April/apr98 p157.pdf

ESREY SA, GOUGH J, RAPAPORT D, SAWYER R, SIMPSONHERBET M, VARGAS J and WINLAD U (eds.) (1998) Ecological Sanitation. Sida, Stockholm, Sweden.

ESREY SA and ANDERSSON I (2001) Ecological Sanitation: Closing the Loop. [online] http://www.ruaf.org/1-3/35-37/.html

HÖGLUND C (2001) Evaluation of the Microbial Health Risks Associated with the Reuse of Source-Separated Human Urine. Swedish Institute of Infectious Disease Control, Stockholm.

JIMÉNEZ B, MAYA C, SANCHEZ E, ROMERO A, LIRA L and BARRIOS JA (2002) Comparison of the quantity and quality of the microbiological content of sludge in countries with low and high content of pathogens. Water Sci. Technol. 46 (10) 17-24.

JIMÉNEZ B, BARRIOS J, MENDEZ J and DIAZ J (2004) Sustainable management of sludges in developing countries. Water Sci. Technol. 49 (10) 251-258.

KIRCHMANN H and PETTERSSON S (1995) Human urine - Chemical composition and fertiliser use efficiency. Fert. Res. 40 149-154.

HEINONEN-TANSKI H and VAN WIJK-SIJBESMA C (2005) Human excreta for plant production. Biores. Technol. 96 403-411. 
HENRY PC and SMITH MF (2006) Two-step approach to determine some useful phosphorus characteristics of South African soils: A review of work done at the ARC - Institute for Soil, Climate and water. S. Afr. J. of Plant Soil 23 64-72.

IUSS WORKING GROUP WRB (2006) World Reference Base for Soil Resources. World Resources Report No. 103. FAO Rome.

LAKER MC (1976) Soil fertility and potential for increased crop production in the South African homelands. Fert. Soc. of S. Afr. J. 2 21-24.

LECO Corporation (2003) Truspec C and N Determinator. Instruction Manual. LECO Corporation, 3000 Lakeview Avenue. St Joseph, MI49085, USA

LENTNER C, LENTNER C and WINK A (1981) Units of Measurements, Body Fluids, Composition of the Body, Nutrition. Geigy Scientific Tables. Ciba-Geigy, Basle.

MANDIRINGANA OT, MNKENI PNS, MKILE Z, VAN AVERBEKE W, VAN RANST E and VERPLANCKE H (2005) Mineralogy and fertility status of selected soils in the Eastern Cape Province, South Africa. Commun. Soil Sci. Plant Anal. 36 2397-2404.

MNKENI PNS, AUSTIN LM and KUTU FR (2005) Preliminary studies on the evaluation of human urine as a source of nutrients for vegetables in the Eastern Cape Province, South Africa. Proc. $3^{\text {rd }}$ Int. Ecological Sanitation Conference. 23-26 May 2005 at the International Convention Centre Durban, South Africa. 418-426. Available online at http://conference2005.ecosan.org/papers/mnkeni et al. pdf

MNKENI PNS, CISNEROS BJ, PASHA MC and AUSTIN LM (2006) Use of Human Excreta from Urine-Diversion Toilets in Food Gardens: Agronomic and Health Aspects. WRC Report No. 1439/3/06. Water Research Commission, Pretoria, South Africa.

MNKENI PNS and AUSTIN LM (2008) Effectiveness of human manure from ecological sanitation toilets as a source of nutrients for cabbage. In: Haneklaus S, Hera C, Rietz R-M and Schnug E (eds.) Proc. $15^{\text {th }}$ Int. Symp. Int. Sci. Centre for Fertilisers: Fertiliser and Fertilization for Sustainability in Agriculture: The First World meets the Third World-Challenges for the Future. 27-30 Sept., 2004, Pretoria, South Africa. 379-392.

MNKENI PNS, KUTU FR, MUCHAONYERWA P and AUSTIN LM (2008) Evaluation of human urine as a source of nutrients for selected vegetables and maize under tunnel house conditions in the Eastern Cape, South Africa. Waste Manage. Res. J. 26 132-139

OKALEBO JR, GATHUA KW and WOOMER PL (2002) Laboratory Methods for Soil and Plant Analysis: A Working Manual ( $2^{\text {nd }}$ edn.) Tropical Soil Fertility and Biology Program, Nairobi, Kenya.

OLSEN SR and SOMMERS LE (1982) Phosphorus. In: Page AL, Miller RH and Keeney DR (eds.) Methods of Soil Analysis (Part 2). Soil Science Society of America, Madison, Wis. 403-430.

OTTERPOHL R, ALBOLD A and GROTTKER M (1996) Integrating sanitation into natural cycles: a concept for cities. In: Staudmann J, Schonborn A and Etnier C (eds.) Recycling the Resource-Ecological Engineering for Waste Water Treatment. Transtec Publications Ltd., Switzerland.

SIMPSON-HERBERT M (1997) Responding to the Sanitation Challenge of the $21^{\text {st }}$ Century. WSSCC, Geneva, Vienna.

SOIL CLASSIFICATION WORKING GROUP (1991) Soil Classification: A Taxonomic System for South Africa. Memoirs on the Agricultural Natural Resources of South Africa, No. 15. Pretoria

VAN DER MERWE AJ, JOHNSON JC and RAS LSK (1984) An $\mathrm{NH}_{4} \mathrm{HCO}_{3}-, \mathrm{NH}_{4} \mathrm{~F},\left(\mathrm{NH}_{4}\right)_{2}$ EDTA Method for the Determination of Extractable $\mathrm{P}, \mathrm{K}, \mathrm{Ca}, \mathrm{Mg}, \mathrm{Cu}, \mathrm{Fe}, \mathrm{Mn}$ and $\mathrm{Zn}$ in Soils. SIRI inf. Bull. B2/2.

VINNERÅS B (2002) Possibilities for Sustainable Nutrient Recycling by Faecal Separation Combined with Urine Diversion. Ph.D. Thesis Agraria 353. Swedish University of Agricultural Sciences, Uppsala.

VINNERÅS B and JÖNSSON H (2002) The performance and potential of faecal separation and urine-diversion to recycle plant nutrients in household wastewater. Biores. Technol. 84 275-282.

VINNERÅS B and JONSSON H (2003) Adapting the proposed Swedish default value for urine and faeces to other countries and regions. Proc. Conf. Ecosan - Closing the Loop. 7-11 April 2003, Lübeck, Germany.

WOLGAST M (1993) Recycling System. Brochure produced by WMEkologen, AB, Stockholm, Sweden.

WRC (1997) Permissible Utilization and Disposal of Sewage Sludge. WRC Report No. TT 85/97. Water Research Commission, Pretoria, South Africa. 